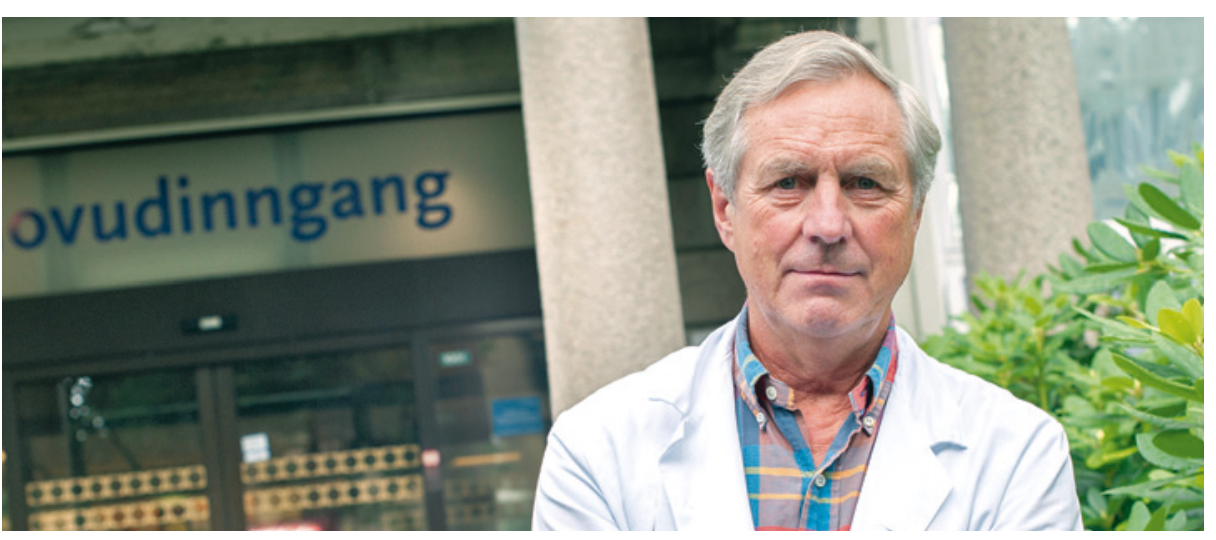

Ole-Erik Iversen er norsk medforfatter av artikkelen. Foto: Informasjonsavdelingen, Haukeland universitetssykehus

\title{
Ny og bedre HPV-vaksine
}

En ny vaksine mot humant papillomvirus (HPV) gir like god antistoffrespons som dagens vaksine og beskytter mot flere virustyper.

Folkehelseinstituttet anslår at rundt $70 \%$ av befolkningen vil få en genital infeksjon med humant papillomvirus i løpet av livet, og at $10 \%$ er smittet til enhver tid. HPVinfeksjon er en nødvendig faktor for utviklingen av livmorhalskreft, der minst 12 HPV-typer har vist seg å være kreftfremkallende.

En kvadrivalent vaksine som beskytter mot HPV-type 6,11, 16 og 18 ble tatt inn i det norske barnevaksinasjonsprogrammet for jenter i 7. klasse fra og med 2009/10. Folkehelseinstituttet angir at denne vaksinen vil kunne redusere antall tilfeller av livmorhalskreft med ca. $70 \%$ gjennom beskyttelse mot HPV-type 16 og 18. HPV-type 6 og 11 gir kjønnsvorter, men er ikke kreftfremkallende. I en ny, stor studie med bidrag fra Norge har man undersøkt effekten av en nivalent vaksine som i tillegg beskytter mot HPV-typene 31, 33, 45, 52 og 58 (1).

Rundt 14000 kvinner i alderen 16-26 år som hadde hatt fire eller færre seksualpartnere, ble randomisert til kvadrivalent vaksine eller den nye nivalente vaksinen. Det ble gitt tre intramuskulære injeksjoner over et halvt år, og pasientene ble fulgt i median tre år. Hver sjette måned ble det tatt prøver fra ytre genitalia og livmorhalsen for HPVDNA-testing og celleprøver til væskebasert cytologisk undersøkelse.

Blant HPV-naive kvinner som hadde fulgt studieprotokollen var det 31 tilfeller av høygradige celleforandringer grunnet HPVtypene 31,33 , 45, 52 eller 58, hvorav 30 tilfeller blant dem som hadde fătt kvadrivalent vaksine og ett tilfelle blant dem som hadde fått nivalent vaksine. Vaksineeffekten mot høygradige celleforandringer forårsaket av de fem nye HPV-typene var altså 96,7 \%. Antistoffresponsen mot HPV-type 6, 11, 16 og 18 var like god for begge vaksinene.
- Tidligere studier har estimert at den nivalente vaksinen gjennom beskyttelse mot de fem nye kreftfremkallende HPV-typene vil kunne øke beskyttelse mot så mye som $90 \%$ av alle tilfeller med livmorhalskreft og $80 \%$ av høygradige celleforandringer, sier Ole-Erik Iversen, som er norsk medforfatter av studien. Oppfølgingen her var begrenset $\mathrm{i}$ tid, slik at studier som følger vaksinerte individer over lengre tid er viktig for å vurdere varigheten av beskyttelsen.

- Det er også rapportert flokkbeskyttelse etter HPV-vaksinasjon. Derfor diskuterer man om det i en populasjon som er gjennomvaksinert med nivalent vaksine vil være mulig å avslutte dagens screeningprogram mot livmorhalskreft, sier Iversen.

\section{Multinasjonal studie finansiert av MSD}

Forfattergruppen bak studien består av vitenskapelige ansatte i MSDs forskningsavdeling og medlemmer av selskapets vitenskapelige rådgivingskomité (Scientific Advisory Committee, SAC). Medforfatterne omfatter også uavhengige forskere som har deltatt i den kliniske utprøvningen av vaksinen. Ole-Erik Iversen, som er professor ved Universitetet i Bergen og overlege ved Kvinneklinikken, Haukeland universitetssykehus, er eneste norske medforfatter.

\section{Lise Mørkved Helsingen}

Tidsskriftet

\footnotetext{
Litteratur

1. Joura EA, Giuliano AR, Iversen OE et al. A 9-valent $H P V$ vaccine against infection and intraepithelial neoplasia in women. N Engl J Med 2015; 372 $711-23$.
}

Publisert først på nett.
Ordforklaringer

Nivalent: Vaksine med antigen mot ni ulike HPV-genotyper. Dagens vaksiner er bi- eller kvadrivalente

Høygradige celleforandringer: Middels og uttalte behandlingstrengende celleforandringer i livmorhalsen (CIN 2/3).

HPV-naiv: Brukes i denne studien om pasienter som etter testing for de relevante HPV-typene var seronegative ved dag 1 og negative ved polymerasekjedereaksjonstest fra dag 1 til og med én måned etter tredje vaksinedose.

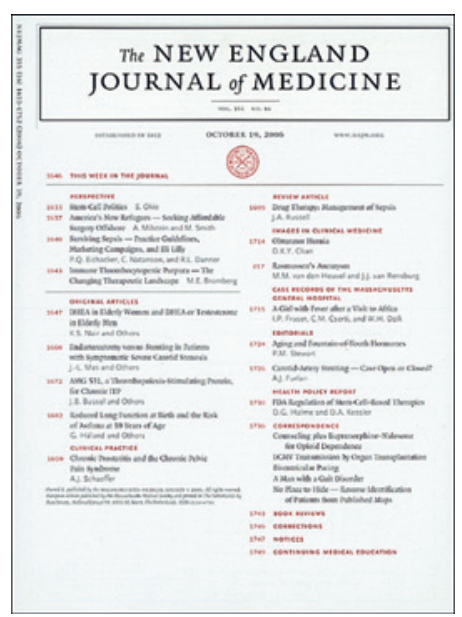

> Artikkelen ble publisert i det prestisjetunge tidsskriftet New England Journal of Medicine 19.2. 2015 